\title{
METAPHYSICAL TREATMENT OF DISEASE AS THE PRACTICE OF MEDICINE
}

Any inquiry into what is meant by the "practice of medicine" may, at first impression, seem purely academic, and so it would have been a generation ago when the healing art was exclusively in charge of physicians schooled in materia medica and the practice of medicine was essentially synonymous with the treatment of disease; but now that new systems for the cure of human ailments have come into existence which have little or no resemblance in method of treatment to what may be styled the established system, in that they make no use of drugs or medicinal substances, the question as to what constitutes the practice of medicine becomes of practical importance, for if the individual who treats disease without recourse to drugs or any of the agencies employed by regular physicians is to be regarded as practicing medicine, he becomes amenable to the criminal law, where, as is usually the case, he is untrained and unlicensed as a physician. Moreover, the people who may desire his method of treatment are thereby denied the privilege of enjoying it and resorting to the practitioner of their choice, while experience in the healing of the sick is restricted to practitioners of the established schools of medicine and is thereby hampered in its growth. These are considerations of vital concern, and are now being so recognized, not only as touching the liberty of practitioner and patient, but as affecting research and progress in the healing art at this time when no school or system has reached that stage of perfection in its practice which warrants it in demanding recognition to the exclusion of all others.

If the average person were asked off-hand to define the "practice of medicine," he probably would reply, in substance, that it is the treatment of disease by means of drugs; but if given time for reflection he would concede that the practice of medicine is something more than merely administering remedies, since the physician first examines his patient, searches for symptoms, and decides the character of the ailment, before determining upon and prescribing the remedy. Medical practice, therefore, includes physical diagnosis; in fact, it is founded thereon. More than this, the physician, after he has diagnosed the case, does not always prescribe medicine, but may advise rest, change of 
climate, or other remedies having no relation to drugs. Yet in doing this he is ordinarily regarded as practicing medicine, because what he does is based upon facts obtained by diagnosis, and presupposes a knowledge of those technical subjects, such as anatomy, physiology, and pathology, which constitutes a medical education. Broadly speaking, one is practicing medicine when he visits his patient, examines him, investigates the source of disorder, determines the nature of the disease, and prescribes the remedies he deems appropriate. ${ }^{1}$

This question seems to have first come up for judicial determination in New York, and on that occasion the supreme court of that state used this language: "The practice of medicine is a pursuit very generally known and understood, and so also is that of surgery. The former includes the application and use of medicines and drugs for the purpose of curing, mitigating or alleviating bodily diseases, while the functions of the latter are limited to manual operations usually performed by surgical instruments or appliances." ${ }^{2}$ The same court, however, has subsequently called attention to the fact that this definition eliminates what it styles as the "very corner stone of successful medical practice, namely, the diagnosis."3

That the practice of medicine includes more than merely prescribing or administering drugs, is recognized in the following statement from the supreme court of Massachusetts: "It would be too narrow a view of the practice of medicine to say that it could not be engaged in in any case or class of cases otherwise than by prescribing or dealing out a substance to be used as a remedy. The science of medicine, that is, the science which relates to the prevention, cure or alleviation of disease, covers a broad field, and is not limited to that department of knowledge which relates to the administration of medicinal substances. It includes a knowledge, not only of the functions of the organs of the human body, but also of the diseases to which these organs are subject, and of the laws of health and the modes of living which tend to avert or overcome disease, as well as of the specific methods of treatment that are most effective in promoting cures. It is conceivable that one may practice medicine to some extent, in certain classes of cases, without dealing out or prescribing

${ }^{1}$ State v. Smith, 233 Mo. 242 , I35 S. W. 465.

${ }^{2}$ Smith v. Lane, 24 Hun 632.

${ }^{3}$ People v. Allcutt, II7 App. Div. 546, I02 N. Y. Supp. 678, affirmed I8g N. Y. 517,8 I N. E. II7I. 
drugs or other substances to be used as medicines. It is conceivable that one may do it in other ways than those practiced as a part of their respective systems, by either 'osteopathists, pharmacists, clairvoyants or persons practicing hypnotism, magnetic healing, mind cure, massage cure science, or the cosmopathic method of healing." "4

"The 'practice of medicine' as ordinarily and popularly understood," declares the supreme court of Tennessee, "has a relation to the art of preventing, curing, or alleviating disease or pain. It rests largely on a knowledge of anatomy, physiology, and hygiene. It requires a knowledge of disease, its anatomical and physiological features, and its causative relations. Popularly, it consists in the discovery of the cause and nature of disease, and the administration, or prescribing of treatment therefor."'s

Since the advent in recent years of drugless systems of healing, and the radical falling off in the use of drugs even by medical practitioners, the legislatures of many states have materially broadened the definition of the practice of medicine by amending the statutes which regulate medical practice and make it unlawful for one to engage therein without first having been examined and licensed by a board of medical examiners. Perhaps the present New York statute is as comprehensive in this respect as any that can be found. It declares that "a person practices medicine . . . who holds himself out as being able to diagnose, treat, operate, or prescribe for any human disease, pain, injury, deformity or physical condition, and who shall either offer or undertake, by any means or method, to diagnose, treat, operate, or prescribe for any human disease, pain, injury, deformity or physical condition."

While within certain bounds legislatures are doubtless competent to define the practice of medicine and thereby restrict the right to engage in it to those who, upon examination, are found to measure up to a prescribed standard of medical knowledge, yet it would hardly be contended that legislatures may so enlarge the definition as to declare that to be the practice of medicine which in its very nature is not, and then make it a criminal offense for any one to engage therein except a licensed medical practitioner. To admit that a legislature has power to do this

'Commonwealth $v$. Jewelle, r99 Mass. 558, 85 N. E. 858.

${ }^{5}$ O'Neil v. 'State, II5 Tenn. 427, 90 S. W. 627, 3 L. R. A. (N. S.) 762, quoting from Am. and Eng. Encyclopedia of Law.

- People v. Cole, I48 N. Y. Supp. 708. 
would be tantamount to conceding that it can declare that to be a crime which in its nature is and under all circumstances must be innocent; and this a legislature, however omnipotent it may be, cannot do. If a person should read Wordsworth's Intimations of Immortality or recite Hamlet's Soliloquy or repeat the Twenty-third Psalm, to a sick person, for a fee, and with the intention of thereby alleviating his suffering, this would not amount to the practice of medicine and no amount of legislation could make it so; and yet we shall presently see that it has been contended, and in some instances successfully, that other acts as far removed as these from actual medical practice, when performed by one who holds himself out to the public as able to bring relief to the sick, amount to the practice of medicine.

In discussing this matter in reference to the medical practice act of North Carolina, Chief Justice Clark of that state observes: "The act is too sweeping. Besides, the legislature could no more enact that the 'practice of medicine and surgery' shall mean 'practice without medicine and surgery' than it could provide that 'two and two make five,' because it cannot change a physical fact. And when it forbade all treatment of all diseases, mental or physical, without surgery or medicine, or by any other method, for a fee or reward, except by a Doctor of Medicine, it attempted to confer a monopoly on that method of treatment, and this is forbidden by the constitution." "

When osteopathic treatment of the sick began to attract public attention some twenty or more years ago, it was called in question as the practice of medicine, but at that time the statutes defined the practice of medicine in its popular or ordinary sense, and the courts very naturally held, in a majority of cases, that the practice of osteopathy is not the practice of medicine, and hence that a practitioner of osteopathy may lawfully pursue his vocation without being licensed as a physician and surgeon. The following language of Justice Clark is instructive in this connection: "It is argued to us that the science, if it be a science, of osteopathy is an imposition. Of that, we, judicially speaking, know nothing. It is not found as a fact in this verdict. We only know that the practice of osteopathy is not the practice of medicine or surgery as commonly understood, and therefore it is not necessary to have a license from the board of medical

'State v. Biggs, r33 N. C. 729, 46 S. E. 401,98 Am. St. Rep. 73I, 64 L. R. A. I39. 
examiners before practicing it. . . The state has not restricted the cure of the body to the practice of medicine and surgery-'allopathy' as it is termed-nor required that, before "anyone can be treated for any bodily ill, the physician must have acquired a competent knowledge of allopathy and be licensed by those skilled therein. To do that would be to limit progress by establishing allopathy as the state system of healing and forbidding all others. This would be as foreign to our system as a state church for the cure of souls. All the state has done has been to enact that, when one wishes to practice 'medicine or surgery,' he must as a protection to the public-not to the doctors-be examined and licensed by those skilled in 'surgery and medicine.' To restrict all healing to that one kind, to allopathy, excluding homeopathy, osteopathy, and all other treatments, might be a protection to doctors in 'surgery and medicine,' but that is not the object of the act, and might make it unconstitutional, because creating a monopoly. . . . Certainly, a statute requiring examination and license 'before beginning the practice of medicine or surgery' neither regulates nor forbids any mode of treatment which absolutely excludes medicine and surgery from its pathology."

Statements to the same effect may be found in the opinions of the Kentucky and Mississippi courts. ${ }^{9}$

Other courts, however, under statutes enlarging the scope of the practice of medicine and giving it a "technical" meaning, have taken the view that the practice of osteopathy, or of its related system, chiropractics, is the practice of medicine, in that such practice involves the diagnosis of disease. ${ }^{10}$ Speaking on . this point the supreme court of Missouri has this to say: "In the main, the cases regard diagnosis as the test to determine whether a practice or treatment is included in the terms 'medicine' and 'surgery.' This is a practical test. A doctor who advises his patient to sleep in the open air is treating him. Such advice, however, based upon a knowledge of the patient's condition obtained by diagnosis. The defendant [a chiropracter] professed to be able to ascertain by examination of the patient

"State v. McKnight, 13I N. C. 717, 42 S. E. 580, 59 L. R. A. I87.

-Nelson v. State Board of Health, $108 \mathrm{Ky} .769,57 \mathrm{~S}$. W. $50 \mathrm{r}$, 50 L. R. A. 383; Hayden v. State, 8I Miss. 29I, 33 So. 653, 95 Am. St. Rep. 47 I.

${ }^{10}$ Bragg v. State, 134 Ala. 165, 32 So. 767; Witty v. State, 173 Ind. 404, go N. E. 627; Swarts v. Siveny, 35 R. I. I, 85 Atl. 33. 
the cause of his trouble, a result rather beyond that which ordinarily attends the diagnosis of the regular practitioner. The method or extent of the examination is not the controlling feature. When the practitioner makes such an examination of the patient as he regards as sufficient to indicate to him the cause of the trouble and its proper treatment, he has diagnosed the case."11

Osteopathy, or some form of manual manipulation, is sometimes practiced in conjunction with mental suggestion, as a means of curing sickness. Persons who adopt this system have been held to come within the meaning of statutes requiring practitioners to take examination before and obtain licenses from the board of medical examiners; in other words, such composite method of treating bodily ailments has been regarded as the practice of medicine. In arriving at this conclusion courts appear to have been guided by the theory that where such treatment is based upon physical diagnosis, as it usually seems to be, it cannot be intelligently administered by one not familiar with anatomy, pathology, and other allied branches of learning. ${ }^{12}$

Suggestive therapeutics, practiced without any manipulation of the body, or use of medicinal substances or material agencies of any sort, and not founded upon diagnosis or assumed knowledge of the laws of health and disease, can hardly be said to constitute the practice of medicine. ${ }^{13}$ This question has been thoroughly considered in Georgia, ${ }^{14}$ where the code provides as follows: "The words 'practice medicine' shall mean to suggest, recommend, prescribe or direct, for the use of any person, any drug, medicine, appliance, apparatus or other agency, whether material or not material, for the cure, relief, or palliation of any ailment or disease of the mind or body, or for the cure or relief of any wound, fracture, or other bodily injury or any deformity, after having received or with the intent of receiving therefor, either directly or indirectly, any bonus, gift, or compensation."

Justice Hill, in interpreting this statute, observes: "The purpose of the act is clearly indicated by its title, 'To regulate the practice of medicine.' It was not intended to regulate the practice of mental therapeutics, or to embrace psychic phenomena. These matters lie within the domain of the supernatural. Prac-

${ }^{11}$ State v. Smith, 233 Mo. 242, I35 S. W. 465.

${ }^{12}$ Smith v. State, 8 Ala. App. 352, 63 So. 28, affirmed 63 So. 70; People v. Trenner, 144 I11. App. 275.

${ }^{13}$ State v. Laweson, 65 Atl. (Del.) 593.

${ }^{13}$ Bennet v. Ware, 4 Ga. App. 293, 6I S. E. 546. 
tical legislation has nothing to do with them. If they are a part of a man's faith, the right to their enjoyment cannot be abridged or taken away by legislation. ... To the iconoclast who denounces these things as the figments of superstition, or to the orthodox physician who claims for his system all wisdom in the treatment of human malady, we commend the injunction of him who was called 'the Good Physician,' when told that others than his followers were casting out devils and curing diseases: 'Forbid them not.'

"Going back to the question now under consideration, we deduce the following proposition: That the practice of medicine defined by the code, supra, is limited to prescribing or administering some drug or medicinal substance, or to those means and methods of treatment for prevention of disease taught in medical colleges and practiced by medical practitioners; that the purpose of the act regulating the practice of medicine was to protect the public against ignorance and incompetency by forbidding those who were not educated and instructed as to the nature and effect of drugs and medicine, and for what diseases they could be administered, from treating the sick by such medical remedial agencies; that the law is not intended to apply to those who do not practice medicine, but who believe, with Dr. Holmes, that it would be good for mankind, but bad for the fishes, if all the medicines were cast into the sea,' nor to those who treat the sick by prayer or psychic suggestion. In the language $e^{15}$ of Chief Justice Clark, 'Medicine is an experimental, not an exact science. All the law can do is to regulate and safeguard the use of powerful and dangerous remedies; . . . but it cannot forbid dispensing with them.' 'All the law so far has done or can do is to require that those practicing on the sick with drugs . . . shall be examined and found competent by those of like faith and order.'

"We are therefore clear that plaintiff in error [who claimed to effect cures by the laying on of hands, the healing resulting from 'Magic power'] was not a practitioner of medicine in the sense of our statute or in the popular sense; and the fact that he received fees and compensation for treatment in the shape of gifts could not make what would otherwise not be the practice of medicine a violation of the statute regulating such practice,

${ }^{15}$ State v. Biggs, I33 N. C. 729, 46 S. E. 40I, 98 Am. St. Rep. 73I, 64 L. R. A. I39. 
for it must be apparent that, if the mere laying on of hands amounts to the practice of medicine in any sense, it is so without reference to fee or reward."

It has been affirmed that suggestive therapeutics bears no relation to the exercise of religious beliefs or principles, and hence is not protected by provisions in a medical practice act which exempt from its operation the practice of religion or any kind of treatment by prayer. ${ }^{16}$ It has also been decided that the fact that a practitioner may believe in the teachings of Jesus relative to healing the sick does not save his treatment from being regarded as the practice of medicine, if, contrary to such teachings, he diagnoses disease and treats patients by rubbing and manipulation. ${ }^{\mathbf{1 7}}$

In Colorado it has been decided that one who holds himself out to the public as a "healer," maintains an office, and accepts compensation for treating the sick, claiming that his treatment is a natural gift, practices medicine, although he makes no use of drugs or surgical instruments. ${ }^{18}$ The practitioner in this case seems to have regarded the treatment of the sick as a part of his religion, and to have invoked the provision of the statute that "nothing in this act shall be construed to prohibit the practice of the religious tenets or the general belief of any church whatsoever, not prescribing or administering drugs." But the court said: "He held himself out to the public as a professional healer of diseases, and a practitioner of the healing art. The statute lays hands on commercial healing as a money-making occupation, business, or profession, regardless of the method of treatment or curative agency employed. . . . The practice of medicine, defined by our statute, means the practice of the healing art commercially, regardless of the curative agency employed. The commercial practice of healing by prayer, followed as a money-making venture or occupation, is the practice of medicine within the plain meaning of the statute."

Here is suggested a novel test for determining whether or not any particular treatment constitutes the practice of medicine, namely, is the service rendered for compensation or gratuitously, is it profitable to the practitioner or otherwise? It is difficult to understand how the matter of compensation can have any bearing on the question, but of this more will be said hereafter.

${ }^{16}$ State v. Pratt, I4I Pac. (Wash.) 3is.

${ }^{17}$ State v. Peters, 87 Kans. 265, 123 Pac. 751.

${ }^{13}$ Smith v. People, 5 I Colo. 270, II7 Pac. 6I2, 36 L. R. A. (N. S.) I58. 
In a recent New York case it appears that the defendant held himself out as curing all sorts of diseases, and that he was the head of a church which he owned and in which he offered prayers and conducted services intended to heal the sick. When prosecuted for practicing medicine without a license, he sought refuge in the provision of the medical act that it "shall not be construed to affect . . . the practice of the religious tenets of any church," but the court ruled against him and he was convicted.19

It is not easy to reconcile this decision with an earlier case in the same state where a parent, or one standing in loco parentis, was indicted for not calling medical aid for his sick child as required by statute, and he interposed the defense that he did not believe in physicians but that he believed in and relied upon prayer for healing. But that was held to be no defense and he was convicted. ${ }^{20}$ Now, if the treatment of disease by prayer or religious ceremonies is the practice of medicine, was not the parent furnishing medical aid when he prayed for the child?

The statutes and decisions referred to in the preceding pages are of course not intended as exhaustive of the subject with which they deal, but merely as representative of the utterances of courts and legislatures in their attempts to determine what constitutes the practice of medicine. Some of the statutes and decisions, but by no means all of them, reveal an unmistakable tendency toward holding that the practice of medicine is co-extensive with the treatment of disease, and that any form of treating disease, especially if for compensation, amounts to practicing medicine, notwithstanding the treatment bears not the slightest resemblance to medical practice as understood and conducted by physicians.

The most striking illustration of this tendency is afforded in the case of Christian Science. Its practice, as everyone knows, is purely metaphysical. It takes no cognizance of physical diagnosis, it eschews drugs and other material remedies, and does not depend upon a knowledge of the functions of the human body or of the diseases to which it is subject. In short there is nothing in common between medical practice and metaphysical or Christian Science practice, except that both are striving to overthrow disease, the former having the physical or mental

${ }^{10}$ People v. Spinelle, I50 App. Div. 923, I35 N. Y. Supp. I133, affirmed in 206 N. Y. 709, 99 N. E. III4, and reviewed in 148 N. Y. Supp. 719.

${ }^{20}$ People v. Pierson, I76 N. Y. 20I, 68 N. E. 243, 98 Am. St. Rep. 666, 66 L. R. A. I87. 
recovery of the patient as its sole object, the latter regarding his physical or mental restoration only as an incident of his spiritual regeneration. And yet, since Christian Science assumes to heal disease, its practice has been challenged as the practice of medicine, and its practitioners have in some instances been prosecuted for pursuing their vocation without being licensed as physicians.

In two of the states of the Union, Missouri and Rhode Island, where this question has arisen, it has been decided that the application of Christian Science to the cure of bodily ailments is not the practice of medicine, and that a Christian Science practitioner, who treats the sick by prayer or metaphysical processes, is not a physician, and hence does not offend the law by carrying on his practice without a license from the board of medical examiners. ${ }^{21}$ Said the supreme court of Rhode Island: "Medicine, in the popular sense, is a remedial substance. The practice of medicine, as ordinarily or popularly understood, has relation to the art of preventing, curing, or alleviating disease or pain. It rests largely in the science of anatomy, physiology, and hygiene. It requires a knowledge of disease, its origin, its anatomical and physiological features, and its causative relations; and, further, it requires a knowledge of drugs, their preparation and action. Popularly, it consists in the discovery of the cause and nature of disease and the administration of remedies and the prescribing of treatment therefor. Prayer for those suffering from disease, or words of encouragement, or the teaching that disease will disappear and physical perfection be attained as a result of prayer, or that humanity will be brought into harmony with God by right thinking and a fixed determination to look on the bright side of life, does not constitute the practice of medicine in the popular sense."

In Nebraska, on the other hand, it has been held that a Christian Science practitioner comes within the statute of that state providing that "any person shall be regarded as practicing medicine . . . who shall operate on, profess to heal, or prescribe for or otherwise treat any physical or mental ailment of another"; and that the practice of Christian Science, for compensation, is an indictable offense, if the practitioner is not a licensed physician. The defense interposed in this case as well as in all other cases where Christian Science has been assailed, was that to declare such treatment unlawful would be to abridge religious

${ }^{21}$ Kansas City v. Baird, 92 Mo. App. 204; State v. Mylod, 20 R. I. 642, 40 Atl. 753 , 4I L. R. A. 428. 
freedom; but Justice Ryan, in rendering the decision replied: "It is confidently believed that the exercise of the art of healing for compensation, whether exacted as a fee or expected as a gratuity, cannot be classed as an act of worship. Neither is it the performance of a religious duty.",22

In Ohio, also, the giving of Christian Science treatment, for a fee, for the cure of disease, has been held to be practicing medicine within the meaning of a statute which declares that "any person shall be regarded as practicing medicine or surgery or midwifery within the meaning of this act, who shall use the words or letters 'Dr.,' 'Doctor,' 'Professor,' 'M.D.', 'M.B.,' or any other title, in connection with his name, which in any way represents him as engaged in the practice of medicine or surgery or midwifery, in any of its branches, or who shall prescribe, or who shall recommend for a fee for like use any drug or medicine, appliance, application, operation or treatment, of whatever nature, for the cure or relief of any wound, fracture or bodily injury, infirmity or disease."

In construing this statute the court states that it has no doubt the legislative intent was to bring within this definition every person who, for a fee, prescribes or recommends a cure for disease, even though the cure is to come not from himself but, through his intercedence, from God. If the practitioner informed against prayed for the recovery of the sick, says the court, then that was the treatment which he gave for the cure of disease and for which he was paid; he was practicing healing or curing disease. "To assume that legislation may be directed only against the administering of drugs or the use of the knife is to take a too narrow view. The subject of the legislation is not medicine and surgery. It is the public health or the practice of healing."

These statements the court makes in answer to the argument of the defendant that the word "treatment" is to be given its meaning as used in the practice of medicine, and that as so interpreted it means the application of remedies to the curing of disease, that a remedy is a medicine or application or process, that a process is an action or operation, and that prayer for the recovery of the sick is neither; it being conceded that the defendant did not recommend or prescribe for the cure or relief of patients any drug, medicine, appliance, application or oper-

${ }^{22}$ State v. Buswell, 40 Neb. I58, N. W. 728, 24 L. R. A. 69. 
ation, that he made no diagnosis or physical examination, that he gave no directions as to food, diet, exercise or any other directions, and that he made no inquiry as to the nature of the disease with which patients were afflicted. The only thing he did was to give treatment by prayer. He was called to see the patient for rheumatism, but saw him only once, and after that gave him absent treatment for one week, at the end of which time the patient paid him five dollars for his services. ${ }^{23}$

A like conclusion has recently been reached, by a divided court, in New York, under a statute providing that "a person practices medicine within the meaning of this act, except as hereinafter stated, who holds himself out as being able to diagnose, treat, operate, or prescribe for any human disease, pain, injury, deformity or physical condition, and who shall either offer or undertake, by any means or method, to diagnose, treat, operate, or prescribe for any human disease, pain, injury, deformity, or physical condition."

This definition of the practice of medicine, declares the court, is broad enough to cover the acts of the defendant, a Christian Science practitioner, "because he 'holds himself out as being able to . . . treat. . . any human disease,' and he did 'undertake to treat.' The language of the statute is 'by any means or method.' This covers the means or method used by him. While he denied the material existence of disease and said it was merely mental, yet he undertook to treat people he called patients for what they told him was the matter with them; in other words, what they thought were diseases. He had an office for that purpose; he received fees therefor; he habitually terms what he did his 'treatment.' He conducted a pecuniarily successful business. He called himself a practitioner, but admitted that the popular phrase was healer."

The court then comes to the conclusion that the acts complained of, that is, the treatment of patients by prayer, in an office maintained for that purpose, for compensation, constitutes the practice of medicine, not the practice of the religious tenets of any church, and to authorize the defendant to administer the treatment, which he concedes he did, he must have first been duly licensed and registered in accordance with the provisions of the public health law. ${ }^{24}$

${ }^{23}$ State v. Marble, 72 Ohio 21, 73 N. E. I063, I06 Am. St. Rep. 570, 2 Ann. Cas. 898 , 70 L. R. A. 835.

${ }^{24}$ People v. Cole, r 48 N. Y. Supp. 708. 
The circumstance which, according to these decisions of the Nebraska, Ohio and New York courts, seems to stamp the practice of metaphysics or Christian Science as the practice of medicine, is that the patient pays and the practitioner receives money for the service rendered. If the treatment is gratuitous, it is the practice of religion; if it is for compensation, it becomes the practice of medicine, notwithstanding the practitioner makes no physical examination or diagnosis ("the very corner stone of successful medical practice"), uses none of the remedies which physicians use, and takes no cognizance of the laws of health and disease as understood by medical practitioners.

This test, that is, the matter of compensation, is not easy to appreciate. It will be noted, by reference to preceding pages, that in determining whether osteopathy or its allied systems constitute the practice of medicine, the test seemed to be, was the treatment based upon knowledge obtained by diagnosis? But now, in dealing with metaphysical practice, pecuniary compensation is made the crux of legality, a thing which has nothing to do with the treatment itself, for the treatment is exactly the same, whether it is paid for or not. If compensation is the test, then the conclusion follows that a practitioner in affluent circumstances may carry on an extensive practice, making no charges, without offending the law, while his neighbor who must depend upon his labors for a livelihood, and who accordingly receives pay for his services, violates the law.

At this point the question naturally presents itself, does a physician practice medicine when he diagnoses and prescribes without receiving any fee, or only when he is paid for his services? It is a matter of common knowledge, and a circumstance that has characterized the medical profession as unselfish perhaps above all others, that the physician stands ready to give his best time and talent to the alleviation of the suffering even of those from whom there is no expectation or possibility of pecuniary reward. Yet in so doing it is safe to affirm that it never occurs to him, nor to any one else, that he is not practicing medicine.

Suppose a physician is careless or negligent in administering medical treatment. Does the fact that he is acting gratuitously relieve him of responsibility? Not in the least. That fact does not modify his liability, for it does not qualify his acts and make them any less the practice of medicine. He cannot defend a suit for malpractice, nor mitigate a recovery against him, on the 
ground that his services were performed without expectation of pecuniary recompense. ${ }^{25}$

Suppose, again, that an individual, untrained and unlicensed as a physician, should presume, without compensation, to diagnose disease, prescribe drugs, perform surgical operations, and hold himself out generally as a physician and surgeon. Would the fact that he acts gratuitously be any defense to a prosecution for practicing medicine without a license? Obviously it would not.

The further the idè of compensation is pursued the more apparent does it become that compensation is wholly irrelevant to the issue. Take away compensation from medical practice, and that practice loses no essential characteristic; add compensation to metaphysical or Christian Science practice-a practice which excludes everything comprehended in ordinary medical practice - and metaphysical practice is not thereby converted into the practice of medicine. If Christian Science is medicine, it must be so for some other reason than because pecuniary reward comes to the practitioner.

Compensation is no part either of medical or metaphysical practice. It is simply an incident thereof. It is recognition of the practitioner's efforts, which ordinary honesty impels the patient to make if he is able to do so. And every practitioner, be he matter-physician or metaphysician, knows that the patient who pays for his treatment, and thereby attempts to give an equivalent for what he receives, is more likely to obtain relief from his infirmities than the patient who is unwilling to make a just return for what is given him.

But it is said that to pay for Christian Science or metaphysical treatment is to commercialize prayer and religion. Yet the judges who have voiced this sentiment would hardly admit that justice is commercialized because there are salaries connected with their offices. And it has perhaps never occurred to any one that religion is commercialized when clergymen are paid for their sermons and prayers. No one harbors the suspicion that religion or justice suffers in quality or is any the less religion or justice because clergymen and judges are paid for their time and labors. They could not exist without compensation, and no right-minded person raises any objection to their being rewarded financially. for the faithful discharge of their duties. And perhaps no exception would be taken to remunerating metaphysical prac-

${ }^{25}$ McNevins v. Lowe, 40 Ill. 209; Peck v. Hutchinson, 88 Iowa 320, 55 N. W. 511 ; Becker v. Janinski, 27 Abb. N. C. 45, I5 N. Y. Supp. 675. 
titioners if their practice were not attracting patients from the established systems of healing.

The unbiased observer can hardly help observing the appositeness here of the incident narrated of Demetrius in connection with Paul's ministry. The narrative states that Paul, after sending Timotheus and Erastus into Macedonia, "himself stayed in Asia for a season. And the same time there arose no small stir about that way. For a certain man named Demetrius, a silversmith, which made silver shrines for Diana, brought no small gain unto the craftsmen; whom he called together with the workmen of like occupation, and said, Sirs, ye know that by this craft we have our wealth. Moreover ye see and hear, that not alone at Ephesus, but almost throughout all Asia, this Paul hath persuaded and turned away much people, saying that they be no gods, which are made with hands; so that not only this our craft is in danger to be set at nought; but also that the temple of the great goddess Diana should be despised, and her magnificence should be destroyed, whom all Asia and the world worshippeth. And when they heard these sayings, they were full of wrath, and cried out, saying, Great is Diana of the Ephesians."20

The argument is urged that Christian Science forfeits its claim to being the practice of religion and is properly classified as the practice of medicine, because Jesus, upon whose teachings Christian Science professes to be founded, taught and healed gratuitously. This contention does not take into account that society and its ways have changed in the nineteen hundred years which have elapsed since Jesus taught on the shores of Galilee. In those days the custom was for the religious teacher to be lodged and fed by those who received his instruction. The people opened their doors to him and received him as a guest. The same principle was exemplified later, in the history of our own race, when bard and poet were dependent upon the hospitality of those whom they entertained, and even the more serious litterateur might look, with entire propriety, to his admirers for maintenance. But now men of letters sell their productions for so much a word or page in quite as matter of fact sort of way as other wares are vended, while singers command salaries not infrequently transcending those paid high officials and dignitaries. In these days all things have, in a sense, become

\footnotetext{
${ }^{20}$ Acts of Apostles XIX, 22-28.
} 
commercialized; people are willing to pay for what they receive and expect to be paid for what they do. And the man who would attempt to depart from this established order might find himself as sadly awry as Hamlet when he cried:

The time is out of joint; O cursed spite,

That ever I was born to set it right!

But if the Bible is to be taken as authority on this question, it will be remembered that away back in Deuteronomy ${ }^{27}$ the wisdom of conversation was crystallized in the law of Moses, "Thou shalt not muzzle the ox when he treadeth out the corn"-an admonition which attorneys even to this day do not forget when their fees are in issue, and which the greatest of lawyers emphasized in his first epistle to the Corinthians, ${ }^{28}$ and later, in his first letter to Timothy, ${ }^{29}$ coupled with the more familiar aphorism, "The laborer is worthy of his reward."

Jesus himself announced the same wholesome doctrine when, according to Matthew, ${ }^{30}$ he declared, "The workman is worthy of his meat," and, according to Luke, "The laborer is worthy of his hire." This he stated in the course of his instructions to his disciples when he sent them abroad to preach and heal; and later on, just before his seizure by the mob after that memorable night at Gethsemane, he said to them: "When I sent you without purse, and scrip, and shoes, lacked ye anything? . . . But now, he that hath a purse, let him take it, and likewise his scrip." 32

Justice Laughlin, in his concurring opinion in the New York case heretofore referred to, draws a distinction in favor of Christian Science practice in a church or at the house of the members of the church. "I am of opinion," he says, "that the acts performed by the defendant [metaphysical treatments given at his office for compensation], if performed in a Christian Science church or in visiting the members of the church or others, and so administering to them without charge, would not violate the statute." But no reason for such distinction has been advanced. Possibly, however, the idea that the place where treatment is

${ }^{27}$ Deuteronomy XXV, 4 .

${ }^{28}$ I Corinthians IX, 9.

${ }^{29}$ I Timothy V, 18.

${ }^{s 0}$ Matthew $X$, Io.

${ }^{31}$ Luke $X, 7$.

${ }^{32}$ Ibid., XXII, 35-36. 
given is a material circumstance in determining its character as medicine or religion, springs from that limited concept which associates religion with church and home life only, and does not see its application to everyday work and business, nor recognize that it may be practiced in all places and at all times.

The attempt to make metaphysical or Christian Science practice unlawful is based on the theory that it is inimical to public health and safety, but no reason is apparent why the practice would be less dangerous in a home or church than in an office. In truth it is not generally supposed that the practice is dangerous; but if it is, its suppression should be for some weightier consideration than that it is carried on in an office rather than at the homes or churches of patients.

In a dissenting opinion in the New York case Justice Dowling differentiates the defendant's metaphysical practice from ordinary medical practice, and in part says: "I do not believe the pursuit in which the defendant [a Christian Science practitioner] was engaged was the practice of medicine. So far from that being the case, the record shows that the defendant disavowed any personal ability or power to influence or affect the condition of the person seeking relief, and urged in every possible way the view that God alone, whom he called the 'Great Physician,' could cure what was called 'disease,' and that those who lived honest, pure, and kindly lives would remain well. He emphasized the fact that God was the only healer, and that prayer to God was the only efficacious means for relief. He practiced no deceit, and made no false professions of ability to be of service. He disavowed any mysterious element in his own practices, and told the witness that by reading Mrs. Eddy's works she could master the means for obtaining relief as well as he had done. Starting with the negation of the existence of disease as a physical fact and following it up with the statement that what is ordinarily recognized as the presence of disease is simply evidence of 'a lack of harmonious relation with the Almighty, he suggested as the only recourse the restoration of a proper spirit of harmony with, and obedience to, the Maker, which condition could be brought about by the person who came to him for help without his assistance, but to bring about which condition he was willing to assist if she so desired. He made no diagnosis; he made no effort to determine the existence or non-existence of any specific disease; he performed no manipulations, passes, or any physical acts tending to create a belief that he was exercising visibly any power 
to relieve the witness; he made no claim of any power resident in himself to relieve any condition which might exist in her.

"Herein, it seems to me, is where what he did fails to bring him within the scope of the statute. That statute as quoted defines one as practicing medicine who holds himself out as being able 'to diagnose, treat, operate or prescribe for any human disease, pain, injury, deformity, or physical condition, and who shall either offer or undertake, by any means or method, to diagnose, treat, operate or prescribe for any human disease, pain, injury, deformity or physical condition.' These four words, 'diagnose, treat, operate or prescribe,' seems to me to refer to acts performed by a practitioner which imply not only affirmative action upon his part, but the assumption and claim of ability to produce results by his own intervention and skill. The Century Dictionary defines 'treat' as: 'To manage in the application of remedies, as, to treat a fever or patient.' This implies action by the person assuming to treat. When one goes to a physician for diagnosis, treatment, operation, or prescription of a remedy, one does so in reliance upon the skill, knowledge, or experience of the physician, and in the belief that he will apply to the best of his ability the sum of his experience and knowledge in the alleviation of the patient's physical illness. There can be no such reliance called for or expected in one who makes no profession of knowing anything of disease, who, in fact, denies its existence, and who simply undertakes to intercede with the Almighty for the extension of His mercy in restoring the balance of one who deems himself ill."

While courts have at various times essayed to define the practice of medicine, they have not formulated any definition of Christian Science practice, further than to designate it as prayer. Indeed, the Ohio court ${ }^{33}$ makes the frank confession, "What Christian Science is we do not know." Manifestly a well-defined idea of what constitutes this metaphysical practice is a condition precedent to determining whether or not it is the practice of medicine, and hence its definition cannot logically be longer deferred in the present discussion.

Christian Scientists themselves style their treatment of the sick as prayer, and therefore cannot be heard to object if the law so defines it. But what is prayer? It has a different meaning to different individuals, just as the word God has. To some people

${ }^{33}$ State v. Marble, 72 Ohio 2I, 73 N. E. I063, I06 Am. St. Rep. 570, 2 Ann. Cas. 898 , 7o L. R. A. 835 . 
$\mathrm{He}$ is a corporeal being, while to others $\mathrm{He}$ is ever-present life or mind. To one $\mathrm{He}$ is anthropomorphic, having not only a human form, but also being swayed by the same passions that toss men to and fro; while to another $\mathrm{He}$ is eternal, omnipresent principle, without variableness or shadow of turning.

Abraham, when he was about to offer up his only son on the altar, conceived of God as a being who demanded human sacrifices; and Jacob thought of Him as having a local habitation, until the vision of angels ascending and descending on the ladder as he slept at Bethel revealed to him that the Lord was even in that place. On the other hand, Jesus recognized God as spirit, John saw Him as love, Paul declared "in Him we live, and move, and have our being," and the Psalmist sang:

If I take the wings of the morning

And dwell in the uttermost parts of

The sea; even there shail thy hand lead me

And thy right hand shall hold me.

It is the realization of the divine immanence, the presence, the allness and the availability of God, and the consequent absence and nothingness of disease and evil, which constitutes treatment by prayer. The prayer is not a pleading with God to deliver the afflicted from their suffering, but rather a knowing that sickness and suffering have no existence in His presence, however real they may seem to human sense looking through a glass darkly. In the consciousness thus clarified and uplifted, pain and disease lose their reality and disappear, while health and harmony are recognized as the facts of existence.

This, of course, is not intended as a full presentation of metaphysical treatment. It is well understood that years of study and labor are required to gain any adequate conception of its processes, and it would be too much to expect complete elucidation in a few paragraphs. In fact the subject is one that is likely to suffer from any formal statement, for the case is one where the letter killeth. But enough has been said, perhaps, to indicate that metaphysical practice is, as its name discloses, totally unlike medical practice.

The medical practitioner relies upon physical diagnosis, regards disease as a grim reality, and believes in the efficacy of drugs, serums, and other material remedies. The metaphysical practitioner rejects drugs and material curative agencies, repudiates every law of disease known to medical practice, and proceeds 
mentally to demonstrate the unreality of the ills of flesh and of mind. All his efforts and operations are in the mental realm, and his aim is to make the "word flesh," that is, to make spiritual truth, which knows no sickness nor sin, operative and controlling in the minds and bodies of his patients.

And so far is he from resorting to diagnosis that, if he has been educated as a physician, he may find the very habit of diagnosing disease, which he has acquired, a positive hindrance and a thing to be overcome when he undertakes to administer metaphysical treatment, because diagnosis tends to build up and make formidable the disease which he is striving to realize the nothingness of. The same principle is applicable to other branches of medical learning; their possession by the metaphysician is less likely to help than to hinder him in his practice. Hence it is that he can see no reason why the law should compel him to qualify in pathology, materia medica, and surgery before he may. pursue the vocation of metaphysical healing. He can make no use of the immense learning that has accumulated on those subjects, and may even find it an encumbrance when acquired.

There seems, then, nothing in common between the metaphysical treatment of disease and the practice of medicine, and hence no valid reason appears for holding that the first is comprehended within the latter. As a matter of fact they are contraries and each excludes the other. At no point do they approach or resemble one another. They merely have a common purpose, the alleviation of pain and suffering. And certainly there is enough of distress on earth to-day in the form of sickness and disease, whether they are regarded as stern realities as affirmed by the materialist or as illusions of the human mind as asserted by the idealist, to occupy the attention of all schools of healing, physical and metaphysical; and the world will be pleased to see these various schools direct more energy toward the overcoming of the ills of flesh and less toward the overthrowing of one another. Suffering humanity is coming to have less and less patience with the controversies which have characterized the last hundred years of medical history, and which have seldom been more intense than now. It demands that its ailments be cured, rather than that this or that school or system be given exclusive place as the well-spring of medical virtue. Orthodox medicine has had full sway during all the long centuries that have passed since Hippocrates formulated his first prescription, yet disease and 
mortality still stalk among men, unswallowed up of health and immortality. The metaphysicians, after scarcely more than two score years of experience, are already certain that they have the universal panacea; but until they can speak to disease with authority as did the Master, it certainly will not be unbecoming of them to advance their claims with less assurance than has sometimes been their disposition, and to see to it, when their power increases as now seems to be destined, that they do not manifest that spirit of intolerance toward others which they believe has been shown toward them. Meanwhile mankind will gladly accept anything from any source which assures relief from its infirmities, and will stand ready to recognize, without persuasion or compulsion, that school or system which attains the high mark of infallibility.

SaN Francisco.

Peter V. Ross. 